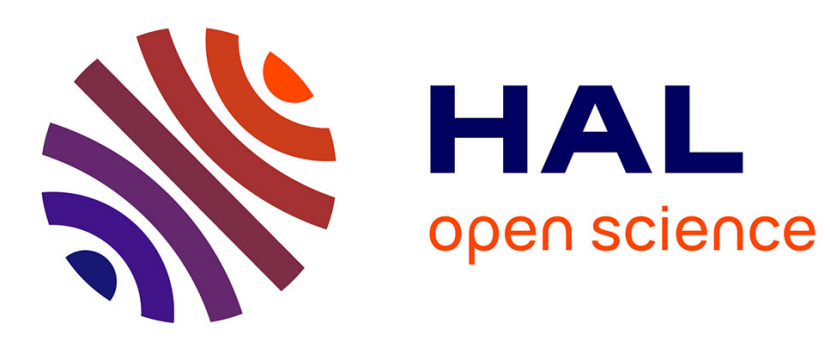

\title{
Contextualizing Corporate Political Responsibilities: Neoliberal CSR in Historical Perspective
}

\author{
Marie-Laure Salles-Djelic, Helen Etchanchu
}

\section{To cite this version:}

Marie-Laure Salles-Djelic, Helen Etchanchu. Contextualizing Corporate Political Responsibilities: Neoliberal CSR in Historical Perspective. Journal of Business Ethics, 2015, 131 (2), pp.1 - 21. 10.1007/s10551-015-2879-7 . hal-01891961v2

\section{HAL Id: hal-01891961 https://hal-sciencespo.archives-ouvertes.fr/hal-01891961v2}

Submitted on 14 May 2020

HAL is a multi-disciplinary open access archive for the deposit and dissemination of scientific research documents, whether they are published or not. The documents may come from teaching and research institutions in France or abroad, or from public or private research centers.
L'archive ouverte pluridisciplinaire HAL, est destinée au dépôt et à la diffusion de documents scientifiques de niveau recherche, publiés ou non, émanant des établissements d'enseignement et de recherche français ou étrangers, des laboratoires publics ou privés. 


\title{
Contextualizing Corporate Political Responsibilities: Neoliberal CSR in Historical Perspective
}

\author{
Marie-Laure Djelic ${ }^{1} \cdot$ Helen Etchanchu ${ }^{1}$
}

\begin{abstract}
This article provides a historical contextualization of Corporate Social Responsibility (CSR) and its political role. CSR, we propose, is one form of businesssociety interactions reflecting a unique ideological framing. To make that argument, we compare contemporary CSR with two historical ideal-types. We explore in turn paternalism in nineteenth century Europe and managerial trusteeship in early twentieth century US. We outline how the political responsibilities of business were constructed, negotiated, and practiced in both cases. This historical contextualization shows that the frontier between economy and polity has always been blurry and shifting and that firms have played a political role for a very long time. It also allows us to show how the nature, extent, and impact of that political role changed through history and coevolved in particular with shifts in dominant ideologies. Globalization, in that context, is not the driver of the political role of the firm but a moderating phenomenon contributing significantly to the dynamics of this shift. The comparison between paternalism, trusteeship, and contemporary CSR points to what can be seen as functional equivalents-alternative patterns of business-society interactions that each correspond, historically, to unique and distinct ideological frames. We conclude by drawing implications for future theorizing on (political) CSR and stakeholder democracy.
\end{abstract}

Marie-Laure Djelic

djelic@essec.edu

Helen Etchanchu

helen.etchanchu@essec.edu

1 ESSEC Business School, Avenue B. Hirsch, BP 90405, Cergy-Pontoise Cedex, France
Keywords Political CSR - Neoliberalism · Paternalism · Trusteeship · Globalization · Stakeholder democracy

\section{Introduction}

The debate on where the responsibility of business ends and that of government starts is an old one. We can at least trace it back to the 18th century opposition between Mercantilism and Liberalism (Screpanti and Zamagni 2005). In its contemporary version, this debate has been shaped by Milton Friedman's provocative claim that the only responsibility of the corporate executive is to his employers-the shareholders (Friedman 1970). This proposition suggests an axiomatic and even natural separation between business and state responsibilities. Arguably, it remains to this day a structuring "null hypothesis"-from, against or in relation to which most contemporary discussions on Corporate Social Responsibility (CSR) inscribe themselves (Kinderman 2012; Marens 2008).

This "null hypothesis," however, is not neutral in any way but ideologically framed. Friedman's (1970) article revealed, expressed, and formalized a specific and consequential ideological frame. Ideological frames are the cognitive and value lenses that constitute our mental maps, the background worldviews through which individual and collective actors approach, read, and act upon the world (Cheal 1979; Davies and McGoey 2012; Padelford and White 2009; Schmid 1981). With respect to the interplay between business and government, this specific ideological frame put forward by Friedman had five main dimensions-individual wealth maximization is the source of collective welfare; corporations belong to (and should serve) their owners-shareholders; business and politics have different logics; that should be kept as separate as 
possible; and the political sphere should have only a supportive and minimal role. The principled separation of business and state responsibilities hence cannot be apprehended without reference to the framing role of a powerful background worldview or ideology (Davies and McGoey 2012; Padelford and White 2009; Van Dijk 1998). We will refer to that specific ideological frame, as "shareholder value maximization." It is often discussed, in the literature, under the broader label of "neoliberalism" (e.g., Djelic 2006; Harvey 2005; Mirowski and Plehwe 2009).

Within the corpus of CSR research, the "instrumental CSR" paradigm has long been dominant (Garriga and Melé 2004; Margolis and Walsh 2003; Vogel 2005). This paradigm clearly inscribed itself in continuity with the ideological frame expressed by Friedman's "null hypothesis"CSR being legitimate only if it contributed to the maximization of profits and value for shareholders (Mackey et al. 2007; McWilliams and Siegel 2001). In contrast, the recent political turn in CSR research has come to question and critique this separation and some of the ideological assumptions it reveals (Matten and Crane 2005a; Scherer and Palazzo 2007, 2011; Scherer et al. 2009). A key argument in this stream of research is that, in the context of globalization, the boundaries between economic and political spheres are getting increasingly blurred. Globalization entails the weakening role and power of nation states and fosters in parallel a "new political role" for private business (Scherer and Palazzo 2011). As corporations increase in size and operate in multiple countries, they come to "assume enlarged responsibilities in their globally expanded business environments-responsibilities once regarded as genuine governmental responsibilities" (Scherer and Palazzo 2007, p. 1109, emphasis authors). With political CSR, we share the project of moving CSR scholarship beyond the economic and instrumental perspective (Scherer and Palazzo 2011, p. 904). We also agree that globalization changes the nature of the interplay between business and politics. We argue, however, that political responsibilities have not always been in any absolute or natural sense "genuine governmental responsibilities".

Current theorizing on CSR in general and political CSR in particular is largely a-historical. Most studies tracing the origins of CSR go back at most to the 1950s and the work of Howard R. Bowen (Acquier et al. 2011; Carroll 2008, for an exception see Marens 2012, 2013). The focus is mostly on the structuration of a CSR preoccupation and field in the period since the late 1970s-in parallel to the deployment of neoliberal globalization (e.g., Kaplan 2015; Kinderman 2012). This limits, we propose, our capacity to compare and contrast CSR as a particular form of business-society interactions inscribed in a singular worldview with alternatives that would be set in different ideological grounds (Matten and Moon 2008).
This is, precisely, the step we propose to take in this article. To move beyond the economic and instrumental perspective on CSR, we contextualize CSR historically as one form of business-society interactions that reflects a unique ideological framing. The comparison of CSR with alternative patterns of business-society interactions in history and their associated background ideologies allows for a critique of the "null hypothesis" that is more radical, we suggest, than that of political CSR. This historical contextualization shows that the frontier between economy and polity has always been blurry and shifting and that firms have played for a very long time a political role. It also allows us to show how the nature, extent, and impact of that political role changed through history and coevolved with shifts in dominant ideologies.

We explore this empirically through a historical analysis of the political role of firms in two distinct periods-in the context of nineteenth century paternalism in Europe and in the context of corporate/managerial trusteeship in the 1920s in the United States. We outline how the political responsibilities of business were constructed, negotiated, and practiced in both cases. The comparison between paternalism, trusteeship, and current notions of CSR points to what can be seen as functional equivalents-alternative patterns of business-society interactions that each correspond, historically, to unique ideological frames. While contemporary CSR corresponds to a "shareholder value maximization" ideology, we connect paternalism to an ideological frame that we label "authoritarian-owner benevolence" and trusteeship to an ideology that we characterize as "techno-managerial efficiency." The historical cases, furthermore, point to a number of past shortcomings, such as managerial discretion, infantilizing forms of control, or the privatization of politics, which help us make sense, through a mirror effect, of some of the limits of contemporary CSR.

The remainder of this article is organized as follows. We start with a short review of the debates around political CSR. We then discuss our methods-a comparison of two historical ideal-types. In the following two sections, we present in turn the two historical ideal-types that constitute the empirical base for this article. In the discussion section, we contextualize contemporary CSR through a systematic comparison with those historical cases and explore the moderating role played in recent years by neoliberal globalization. Using systematic ideal-type comparison as a conceptualizing device (Glaser 2002), we are able to identify four main dimensions along which the political role and responsibility of firms has varied over time and in parallel to shifting background ideologies. A first dimension is territory-or the range of action and responsibility. Second, we find a striking evolution in the nature of "actors" at the core of this responsibility. Third, targets have 
evolved-reflecting a transformation of those intentions that motivate the exercise of responsibility. Finally, the modes through which responsibility has been exercised have also changed in significant ways. We conclude by drawing implications for future theorizing on (political) CSR and stakeholder democracy.

\section{A Changing Global Landscape: A New Political Turn of CSR?}

Even today, most studies theorizing in economics and management start from the assumption that the business of business is (only) business (and profits) and that maximizing shareholder wealth amounts to maximizing societal wealth. This economic and political paradigm was probably most clearly expressed by Milton Friedman in his wellknown 1970 New York Times Magazine article, entitled "The Social Responsibility of Business is to Increase its Profits." According to Friedman, because managers are understood to be the agents of owners-shareholders (principals), their responsibility is to those shareholders only and to the maximization of their profits (Friedman 1970). Because managers are neither elected nor politically representative, they do not have the legitimacy, on the other hand, to deal with societal and common good issues (Friedman 1970). Hence, Friedman argues, business cannot and should not take on social or political responsibilities. The logic is that of a neat separation between business and society/politics and of a clear division of labor between private business actors - who should only be involved in economic activities and profit maximization-and other actors, including the state, who can and should take on political and social roles. With the progress of globalization, however, a number of scholars point to blurry boundaries between business and government (Crane et al. 2004; Marens 2012; Matten and Crane 2005a; Matten et al. 2003; Scherer and Palazzo 2011). The increasing power of large, often multinational, corporations makes their political role and responsibility unavoidable. Globalization also appears to imply an erosion of state sovereignty and a weakening of state capacities, which may foster even more the political role of business (Matten et al. 2003; Prakash and Griffin 2012; Scherer and Palazzo 2011). In fact, some scholars assert that "globalization has changed the social contract between business and society" (Mark-Ungericht and Weiskopf 2007, p. 286). Others even talk of a paradigm shift (Palazzo and Scherer 2008).

In that context, a lively debate explores the political dimension of CSR, corporate citizenship, and business ethics (Heath et al. 2010; Matten et al. 2003; Scherer and Palazzo 2007). The core argument is that as corporations increasingly take on activities conventionally understood to be the prerogative of governments, even if only to provide public goods necessary to their proper functioning, they take on a political role (Matten and Crane 2005a; Scherer and Palazzo 2007, 2011). When corporations provide public goods through their CSR programs-clean water, health, or education - then CSR indeed has a political dimension (Ite 2004). When corporations seek to address ethical issues in their global supply chains, CSR again is about politics (Rotter et al. 2014). Finally, when corporations get involved in multi-stakeholder rule making, CSR once more becomes politics (Mena and Palazzo 2012).

In contrast to the idea of corporate responsibility and citizenship as means to compensate for government failure stand critics who decry CSR as nothing more than an instrument used to further private interests (Fooks et al. 2013) and to sustain new forms of imperialism, colonialism, and inequality (Banerjee 2007). Both representations of CSR point to its political nature but the meaning of the term "political" is different in each case. We find a continuum of meanings for "political" between "serving the common good"-often valued positively—and "at the service of particularistic interests to the detriment of other groups"-perceived more negatively. Critics of contemporary CSR highlight the fact that corporations only focus on a selection of issues and stakeholders they deem important for their own activities and interests (Banerjee 2011; Devinney 2009; Scherer and Palazzo 2007, 2011). Taken for granted or even celebrated in stakeholder and CSR research, managerial discretion is called upon by critics who argue that "it is dangerous to assume that managers know what is best for society" (Buchholz and Rosenthal 2004, p. 145). Managerial discretion is problematic because of a lack of legitimacy and accountability to stakeholders (Buchholz and Rosenthal 2004) and to society at large (Matten and Crane 2005a; Scherer and Palazzo 2011). The problem is the non-democratic nature of valuation and moral judgment in the assessment of stakeholder interests and their priorities-and this problem begs the question of the legitimacy of the corporate stakeholder model.

Strangely enough, while the normative assessment of CSR as political activity varies significantly, from essentially positive and progressive (Scherer and Palazzo 2007) to negative and even possibly destructive (Banerjee 2007; Fleming and Jones 2012; Fooks et al. 2013), the causal narrative is broadly similar. Across the literature on political CSR, contemporary globalization is presented as the main driver of both CSR and its political role (Banerjee 2007; Matten et al. 2003; Prakash and Griffin 2012; Scherer and Palazzo 2011). The progress of globalization, it is argued, comes together with a "deterritorialization of social, political and economic interactions" that ultimately generates what Matten and Crane call a significant "dis- 
empowerment of states" (Matten and Crane 2005a, p. 171). This frames the context in which corporations "take over many of the roles and actions previously associated with government" and become increasingly involved in administering "citizenship rights" (Matten and Crane 2005a, pp. 170-171).

Mäkinen and colleagues $(2012,2014)$ highlight the fact that contemporary conceptions of political CSR are profoundly embedded within the modern liberal political system. The critique of the "a-political role of the corporation" (Palazzo and Scherer 2006, p. 72) or even the development of the notion of "corporate citizenship" (Matten and Crane 2005a) inscribe themselves within classical liberal political theory (Mäkinen and Kourula 2012). While questioning purely "economic" or "instrumental" CSR, political CSR scholars still paradoxically further the liberal assumption that once upon a time economic and political spheres were stable and separate and that political responsibilities were traditionally the prerogative of states and governments. Even critiques of political CSR and corporate citizenship are in fact likely to take the liberal paradigm of a clear separation of business and politics as a starting point (Jones and Haigh 2007; Van Oosterhout 2005; Willke and Willke 2008). Jones and Haigh (2007), for example, base their strong critique of the deployment of corporate citizenship on game theoretic approaches that take for granted the rational corporation, along with its profit-seeking motive and economic incentive structures. In a rebuttal to this violent critique, Crane and Matten underscore that Jones and Haigh engage, in reality, "in a nostalgic retreat to a Keynesian postwar world where the lines between business, government and civil society were sure and certain" (Crane and Matten 2008, p. 23).

Mäkinen and colleagues take what we see as an important step to distance themselves from the powerful assumptions associated with the "null hypothesis" (Mäkinen and Kasanen 2014; Mäkinen and Kourula 2012). They argue that the separation between business and society, economy and politics, or public and private that we take for granted today may reflect a particular (and hence contextual) socio-political system. Mäkinen and Kourula revive, in the process, an older sociological and anthropological tradition that conceives of society as a more complex, integrated if not "total" phenomenon where the economic, the social, and the political are all deeply interlocked (Hirschman 1981; Mauss 1967 [1925]; Polanyi 1944).

In line with Mäkinen and colleagues and with this older intellectual tradition, we draw attention to the plurality of forms of business-society interactions. We do so by providing a historical contextualization of contemporary CSR. We propose that alternative patterns of business-society interactions in different periods of time reflect, and are framed by, distinct background ideologies. Such a historical contextualization of contemporary CSR and of its associated ideological frame shows that firms are and have always been political actors. Furthermore, it can contribute, we suggest, to a deeper understanding of how this political role has been and is motivated, exerted, legitimated, or even contested through time. In the process, we can learn from questions raised and actions (un)taken in the past to further our understanding of the contemporary political role and responsibility of firms and their consequences.

\section{Epistemological Assumptions and Methods}

Our project in this article is grounded in the epistemological conviction that human activity is contextual, socially constructed, and ideologically framed. Activity, language, institutions, politics, and practices are historically co-constituted and co-evolve with values and ideologies. Hence, words and concepts are not mere labels put on the "essence of things" but "historical and cultural objects," "symbolic systems with their own histories and logics"-symbolic systems that reflect particular ideological frames and are at the same time "modalities of power and authority" (Somers 1995b, p. 232). This kind of epistemological conviction generates a responsibility for the social scientist - that of uncovering ideological frames behind takenfor-granted concepts and practices (Somers 1995a). As Max Weber put it, the social scientist should aim at deep, embedded understanding (verstehen) - an understanding of the worldviews or ideologies that constitute or inform activities, concepts, or interactions, an understanding in other words "of the cultural significance of concrete historical events and patterns" (Weber 1949 [1904], p. 111). In order to really "understand how we think and why we seem obliged to think in certain ways" (Hacking 1990, p. 362), we need to analyze concepts as being "words in their sites" (Somers 1995a, p. 113) and as such embedded both historically and ideologically.

We believe that scholarship on corporate social responsibility (CSR) has tended to neglect this essential dimension of social scientific analysis. An important frontier for scholarship on CSR in general-and on political CSR in particular-should be to explore the institutional, political, and ideological dimensions that coevolve with contemporary notions and practices of CSR. We argue here that a historical contextualization of contemporary CSR is an important step in that direction. CSR needs to be understood as a particular and contextual form of business-society interactions that reflects and reveals certain institutional and cultural conditions, particular relations of power and a given ideological and value grounding. 


\section{A Methodological Program: Ideal-Type Construction and Comparison}

To move in that direction, we engage in the construction of ideal-types for two historical patterns of business-society interactions that pre-date contemporary CSR. The first ideal-type, "paternalism," emerged and developed during the first and second industrialization and was particularly prevalent in nineteenth century Europe. We label the second ideal-type "trusteeship." It emerged alongside corporate and managerial capitalism-hence during the first part of the twentieth century in the United States. Ideal-type construction is a methodological program pioneered by Max Weber and allowing for both an in-depth historical and contextual understanding (verstehen) as well as for conceptualization and theory building through comparison (Weber 1949; Watkins 1952; Doty and Glick 1994; Glaser 2002). An ideal-type is a construct that serves to clarify a particular logic of action or structure of organization by extracting from the thickness of empirical situations not only a pattern of action or structure but also the meaning system in which those are embedded and "make sense" (Weber 1978 [1922], p. 20). The ideal-type is "constructed by abstracting the outstanding features from some historical complex and by organizing these into a coherent worldpicture" (Watkins 1952, p. 23). Hence, ideal-types are heuristic devices that are neither a faithful image of the real world nor the projection of an idealized utopia. They are "mental constructs" and in that sense they "cannot be found empirically anywhere in reality" (Weber 1949 [1904], pp. 91-92). Neither can they be treated as normative, best practice-like projections. Their "ideality" only lies in the associated "simplification and aloofness from detail" (Watkins 1952, p. 23).

A research-design based on ideal-type construction and comparison is not easy to operationalize but it has many advantages. It allows the researcher to combine in-depth understanding of complex and unique historical "wholes" with their reduction and simplification into heuristic constructs that then become tools for comparison and conceptualization. The researcher can compare different idealtypes with each other as well as a particular empirical situation with a given ideal-type. The complexity of deploying a research-design based on comparative idealtypes explains that it is still rarely used, but as a powerful tool for theory building and conceptualization, it is likely to elicit growing interest in the coming years (Baden-Fuller and Morgan 2010; Hernes 2005; Horsfall 2013; Soliva 2007).

This methodological program appeared well suited, in any case, to our two-dimensional project. We wanted to uncover, on the one hand, the complex associations between different patterns of business-society interactions and specific background ideologies. On the other hand, we expected to identify similarities, or functional equivalence, but also striking differences and specificities across these patterns through time. An easier methodological alternative would have been to do an in-depth historical case-study of CSR, exploring both its origins and its development in time (Skocpol 1984; Yin 2014). We would have then also been able to uncover the worldview framing contemporary CSR - and possibly its evolution through time. But the systematic comparison with different patterns of businesssociety interactions and their background ideologies allows us to point to key differences and surprising similarities that help us identify the strengths and weaknesses of contemporary CSR.

The paternalism and trusteeship periods provide us with two ideal-types of business-society interactions, which we can compare and contrast with contemporary CSR. We could have considered, constructed, and used a number of other ideal-types. For example, we could have identified guilds as an alternative pattern of business-society interactions (Kieser 1989). We chose to focus on paternalism and trusteeship first of all because they correspond to periods of (relatively) advanced modernity and articulate with forms of social and economic organization that are close enough to our own. Furthermore, both periods are particularly interesting as they are both characterized, like our contemporary CSR period, by a strong political implication of business. By thus reducing differences between our three periods and ideal-types, we can hope to capture more easily the similarities and differences with respect to how business exercised political responsibility in each case.

\section{Data Collection and Analysis}

Our data sources are mainly secondary material—essentially the work of historians who contributed in-depth explorations and descriptions of the social and political roles of business during each period. On nineteenth century European paternalism, we reviewed a wide-ranging set of company histories on well-known paternalist firms. We further built upon an unpublished doctoral dissertation, which so far represents the most advanced historical contribution on the practices of nineteenth century paternalism in France (De Bry 1980). We also had a 2-h long interview with the historian, author of that dissertation. For the trusteeship era, we had access to secondary material but we also explored some primary archives-open letters or lectures of key managers and opinion leaders in that period. This preliminary phase of historical exploration provided us with the empirical material necessary to construct the two ideal-types.

We constructed the two ideal-types through "synthesis of a great many diffuse, discrete, more or less present 
features" (Weber 1949 [1904], p. 90). The richness of the data was managed and simplified thanks to a structure that we followed in both cases: (1) the historical context, (2) the ideological frame, (3) the main political roles and responsibilities of business at the time, and 4) the political struggles and frictions encountered towards the end of each period. It is important to understand that the ideal-type itself is not-and cannot be-a faithful historical depiction (Weber 1949 [1904]). An ideal-type is a unified construct, a concept but one that cannot be "objective" as it is always constructed from a "point of view," a "perspective," or a "set of presuppositions" (Weber 1949 [1904], pp. 91-92). For the purpose of this study, our perspective and our presuppositions were guided by Matten and Crane's (2005a, b) extended view of corporate citizenship that investigates corporate involvement in the administration of social, civil, and political rights. According to Matten and Crane (2005a, p. 170) social rights "consist of those rights that provide the individual with the freedom to participate in society, such as the right to education, health care, or various aspects of welfare." Civil rights consist of those rights that "provide freedom from abuses and interference by third parties (most notably governments), among the most important of which are the rights to own property, exercise freedom of speech, and engage in "free" markets." Political rights include "the right to vote or the right to hold office and, generally speaking, entitle the individual to take part in the process of collective will formation in the public sphere." We explored our data with these different roles in mind and used this framing as a red thread connecting the various ideal-types beyond their differences and specificities.

Once constructed, historical ideal-types become methodological tools or measuring rods allowing us to understand and characterize concrete periods, events, and situations by confronting them with a particular ideal-type. But it is also interesting to compare different ideal-types between themselves to underscore, beyond the variability of contexts, similarity through functional equivalence as well as remaining and consequential differences (Hall 2007). This is what we do in this article by confronting our two historical ideal-types with contemporary CSR (that becomes a third ideal-type in the process)—and showing how we have in each case alignment between particular patterns of business-society interactions and specific ideological frames. Using the different forms of firm involvement defined by Matten and Crane (2005a) as a red thread, we have tried to systematically draw out similarities and differences, between and across ideal-types, with respect to how business took on political responsibility (i.e., catered to political, social, and civil rights) in each case. This systematic comparison allowed us to identify four principal dimensions along which patterns of business-society interactions varied over time-territory, actors, targets, and modes of political responsibility. "Territory" refers to the geographical reach and scope of political responsibility. "Actors" point to the main carriers of political responsibility. "Targets" are the "objects" at the receiving end of (and hence reveal the intentions of) political responsibility. And "modes" reflect the different ways in which political responsibility is exercised (e.g., Young 2004).

In summary, the construction and comparison of idealtypes allows us to both historicize and de-naturalize contemporary CSR by confronting it to alternative patterns of business-society interactions and suggesting both functional equivalence and striking differences. This confrontation makes it possible to think of bundles and configurations-connecting a form of business-society interactions with certain institutional, cultural, political, and ideological traits.

\section{Nineteenth Century Paternalist Business and its Political Role}

As a pattern of business-society interactions, paternalism emerged and developed in close articulation with a particular form of capitalism. The heyday of paternalism was the mid-to-late 19th century, with a particularly strong inscription in Europe (Hobsbawm 1996; Noiriel 1988; Reid 1985).

\section{Historical Context: Industrialization and Personal Capitalism}

As the European continent was going through its early phases of industrialization, from the late eighteenth century throughout the nineteenth century, an early step was the development of the putting-out system (Nussbaum 2002 [1933]). Intermediaries organized, contracted out to, and pooled production from individuals and households who worked from their homes (Sabel and Zeitlin 1985). Progressively, the idea of bringing producers together in the same physical space-with a view to increasing productivity and control but also to exploiting technological developments-imposed itself. And the factory system came to replace almost everywhere the putting-out system (Hounshell 1984; Nussbaum 2002 [1933]; Pollard 1965). The emergence of the modern factory system was a profound revolution with major economic but also social and potentially political consequences.

The development of the factory system in Europe took place within the frame of personal capitalism (Colli et al. 2003). Factories belonged to firms that were under the strong control and oversight of individuals or small groups 
of owners. Legal structures became more sophisticated by the end of the nineteenth century. On the whole, though, the joint stock corporate form remained rare. Rather, personal legal forms, partnerships, or hybrid structures where strong owners/decision makers opened their capital to passive investors were more widespread.

As Europe went through its first and second industrial revolutions, economic transformations and their substantial and often dramatic societal consequences triggered reactions. The socialist critique in particular denounced profound social disruptions. The break-up of families and rural communities associated with mass migration towards the industrial centers where factories were located, child labor, alcohol consumption and violence, out-of-wedlock pregnancies, poor hygiene, exhaustion from overwork but also work-related accidents and sicknesses with no protection or compensation pointed to the dark side of increased productivity and control (Engels 1987 [1844]). The increasing intensity of that critique combined with a genuine preoccupation for profoundly disrupting social trends to foster action and organization within parts of the European business classes. Paternalism flourished in that context (Magnusson 2000; Nielsen 1994).

\section{The Paternalist Reaction and Its Ideological Frame: Authoritarian-Owner Benevolence}

The common logic behind the paternalist reaction reflected a deeply ingrained ideological frame that we label here "authoritarian-owner benevolence." The firm-and the factory-was understood to be an extension of the owners and their families. Ownership was a source of uncontested power-just like fatherhood at the time. Workers were like children who needed the authority but also at times the guidance and benevolence of the owner/father. Power and wealth implied responsibility with regard to the employees/ children. The space in and around the firm should be protected, as much as possible, from external political encroachments of different kinds. And as a consequence, owners should proactively engage in any political and social activity that would keep external scrutiny and pressure at bay.

Within this broad background ideology, there were variants that reflected distinct but compatible influences. We identify essentially three. First, some expressions of paternalism had clear elective affinities with the "civilizing, white man's burden" associated, for example, with the colonial enterprise or with progressive benevolence of a Benthamian type (Quinn 1997). The paternalist project reflected, in that context, the sense of responsibility that should come with a (perceived) sense of (racial/class) superiority (Gillet 1976). A second strand of paternalism was connected to a Christian form of humanism that underscored the urgent necessity to reconcile the intense development of capitalism with respect for human beings as divine creatures. For example, Léon Harmel, owner of textile mills in the North of France (today in Belgium), saw his company as a "Christian corporation." He targeted the creation of a physical and spiritual community that looked to "the well-being of the workers" and the "prosperity of the enterprise" (Coffey 2003; Harmel 1889, p. 37). A third strand of paternalism was anchored in the intellectual tradition pioneered by Charles Fourier or Robert Owen. JeanBaptiste Godin, who founded the stove company bearing his name, constructed, for example, the structures for a community-the Familistère de Guise-with the objective of reconciling economic production and social progress (Lallement 2009).

Those distinct intellectual influences all provided strong motives for paternalist-type intervention. The ideological driver, however, was often combined with more pragmatic motives, reflecting the fact that firms needed certain resources, including healthy and mobilized workers, quiet and thriving communities, which they could not, in that period, take for granted. On the ground, those different strands of paternalism translated into relatively similar practices. The logic was that the authority of the owner/father implied a certain form of responsibility to the members/employees/children of the firm that went well beyond the provision of a salary. In some of the most extreme variants of the paternalist experience, the firm became fused with the geographical community in which it was embedded. Brede Klaedefabrik north of Copenhagen, Denmark, the Stumm family in the Saar region, Germany, Philips in Eindhoven, Netherlands, Schneider in Le Creusot, France, the tire manufacturer, Michelin in the city of Clermont-Ferrand, France, and Gustaf Adolf Serlachius Company in Mänttä, Finland are all typical examples of how paternal employers across Europe took on social and political responsibilities towards the local community by creating sometimes entire factory towns (De Bry 1980; Gueslin 1993; Kalb 1997; Mäkinen and Kasanen 2014; Mäkinen and Kourula 2012; Nielsen 1994; Van Dülmen 1989).

\section{Political Roles and Responsibilities}

The political roles and responsibilities of nineteenth century paternalist firms were broad. They included the production of public goods and services, the defense of citizenship rights, and, at times, initiatives to foster the democratic empowerment of employees. They also translated into rule making and monitoring, within firms but also beyond. As we have just underscored, the ideology in which paternalism was inscribed explains that nineteenth century employers considered this political role a personal 
(and firm) duty and often even a moral obligation (De Bry 1980, p. 303).

\section{Administering Social Rights Through the Production of Public Goods}

Most paternalist employers provided public goods of a social welfare nature-typically health care, retirement provisions, child-care, and family-connected purchasing power (e.g., De Bry 1980; Nielsen 1994; Reid 1985; Roberts 1958). For example, Léon Harmel understood his obligations to the worker who lived on site to include caring for the family in case of illness, accident, or death of a family member. He also made sure that the worker, his wife, and children performed tasks according to their ability and that they would have sufficient time left to fulfill their duties to their family and to the Church (Coffey 2003). Faced with high levels of childbirth mortality, paternalist employers provided financial assistance, reduced working hours, and organized health and dietary workshops for pregnant women (De Bry 1980). Paternalist employers often granted their workers child or family allowances to encourage larger-size families. Companies also built or financially contributed to the building of collective institutions, such as hospitals, old-age homes, or schools. An observer of the Brede factory community in Denmark described it this way:

All the salaried staff and workers live in houses belonging to the firm and on land belonging to the firm, and for their needs and comfort the firm has set up a library, savings bank, a canteen, a bath house, a school for the children (about 150), a kindergarten for the infants (aged 2-7) and a nursery for the tots (up to the age of 2). (cited in Nielsen 1994, p. 70).

Similarly, within the Godin familistère, workers enjoyed good housing, hygiene, health, education, quality food, clean water, and air, tranquility, etc. (Lallement 2009). For JeanBaptiste Godin, these public goods were the "equivalents of wealth" and they should be deployed to deal with the "social predicaments of industrialization" (Guiol 2000).

Paternal employers, furthermore, tried to reduce the risk of work accidents. They offered pension plans, unemployment benefits, health insurance, and corporate saving schemes (De Bry 1980). They organized or fostered the creation of food and staples' cooperatives to reduce the costs of first necessity products. Some paternal employers even created their own currency and operated their own police force, as the Serlachius Company in Finland illustrates:

The factory owners of Mänttä have hired the first police officers and built the first fire department. The company maintained the phone network until 1954. The company put efforts into building roads and railways. It owned ships, brought the first car to Mänttä in 1913 and maintained the municipality's roads and streets up to 1948. The inhabitants bought their groceries in the company store and paid them with 'Serlachius money'. (Palkkatyöläinen magazine cited in Mäkinen and Kourula 2013, p. 226)

From the Provision of Moral Goods to the Defense of Civil Rights

The production of public goods was often tightly connected with the provision of moral goods. On an everyday basis, paternal employers sought to moralize employees, and material privileges were often seen as a compensation for the "moral" worker. For example, employers built churches or chapels on company grounds and encouraged the reading of "good" newspapers- "good" being defined by their own appreciation. They built schools for the children of their employees and kept tight ideological and moral control over those schools. For example, the schools financed by paternalist Christian employers were operated by nuns-which ensured a strong moral and religious influence on the education of children (De Bry 1980). Paternalist employers would make sure that children actually attended these schools, including through coercive pressure on the family, which could take the form of conditional social welfare benefits (De Bry 1980; Nielsen 1994). The protection of civil rights was thus rather constrained and conditional upon the alignment of workers with employers' values.

However, later in the nineteenth century and in reaction to the increasing socialist critique that was bound to influence their workers, a number of paternalist leaders became active in promoting a certain empowerment of workers. Léon Harmel, for example, played an active role in the creation of Christian trade unionism in France and established himself as a social reformer (Coffey 2003). JeanBaptiste Godin was among the most progressive industrialists of his generation (Godin 1881). He went so far as to create a "work and capital association," through which he turned the property of the means of production over to workers and advocated that everybody should receive according to their needs. This was a step to enfranchise workers and free them from the yoke of paternalist employers. In England, the Tory social reformer, Lord Ashley, called upon the government to take over the definition and enforcement of employee protection. The idea was to disconnect civil rights and social benefits from direct dependence to a paternalist employer (Roberts 1958). But in the 1840s, Lord Ashley's plea went unheeded. 
illegitimate forms of control and abuses of power from

Paternalist owners being the "providence" of their employees set the rules single-handedly within their firms. They also often had an impact at the local community or even at the national level as they exercised political mandates. Eugène Schneider, for example, was mayor of the city where his firm was located, member of the National Assembly between 1845 and 1848 and even Minister for agriculture and commerce in 1851 (De Bry 1980, p. 400). Paternalist owners, hence, could be directly involved in local and national rule making.

Paternalist strategies often had a strong control dimension. Even though Jean-Baptiste Godin was very progressive, his "social palace" (Palais Social) at the heart of the familistère was an architectural expression of how paternalist employers monitored and controlled employees. It evoked the Panopticon, which Jeremy Bentham had developed for the purpose of complete surveillance in hospitals, mad houses, or prisons (Bentham 1995). According to Godin, detailed planning of duties according to one's abilities combined with tight control would bring order and coherence and eliminate conflicts (Lallement 2009). As said before, paternal employers who controlled factory towns had the strongest leverage, monitoring employees well into their private lives. They restricted the journals employees could read, made them go to church, and their children to school. They even organized leisure time by structuring, sponsoring, and even imposing participation into certain activities (sports, cooking, etc.). Some imposed strict rules for house cleaning that were controlled through regular visits (Noiriel 1988). Others even used their own private police forces to control workers. When violent strikes erupted at the mines of Blanzy in France in 1882, the director delegated the recruiting process to his private police to ensure that new hires did not "infiltrate" socialist ideology but instead shared the employer's values (De Bry 1980). Only with the crisis of paternalism did employers come to accept a widening of their employees' political rights, through the development, for example, of non-company trade unions.

\section{Towards a Crisis of Paternalism and the Rise of the Welfare State}

At the turn of the twentieth century, paternalism was in crisis. The increasing influence of the socialist critique that translated into a worldwide organization of the labor movement was an important driver for the questioning of paternalism as a pattern of business-society interactions (Katznelson and Zolberg 1996). There were many violent strikes and brutal riots in that period (Debouzy 1988; Noiriel 1988; Tone 1997). Employees actively denounced paternalist employers (Joyce 1980; Roberts 1958). Paternalism was criticized as a masquerade and the expression of manipulation, leading to the structural infantilization of workers. It was denounced as a dangerous scam-where the class struggle was being diluted in "heated housing programs" and "sports facilities." In parallel, large parts of the working classes and certain strands of socialism mobilized in favor of an alternative- the welfare state.

Throughout Europe, political actors, particularly at the national level, questioned the legitimacy of business control over local community affairs. They looked for ways to constrain the authority of paternalist employers (Reid 1985, p. 598). Increasingly, intrusive governments forced themselves into what had until then been (private) company territories. Paternalist employers fought to keep their authority and control by complying proactively with societal demands for better working conditions and greater respect of workers' political and civic rights. For example, the mining company of Blanzy created a workers association in 1909, which at least in appearance was run by workers (De Bry 1980, p. 304).

But this was not enough and the welfare state progressively imposed itself in Europe as an alternative to the strong political engagement hitherto characteristic of private firms (Beck 1995). In the social democratic view of the welfare state, citizens (and not workers) are granted rights-from education, health, social security, unemployment, and even pension rights. The state becomes in that context responsible for eradicating unemployment and poverty but also wage-dependency (Esping-Andersen 1990; Quadagno 1987):

Laws and regulations of the late nineteenth century mainly based on liberal or social conservative ideas formed a public sector which became an alternative to private responsibility for workers (De Geer et al. 2009, p. 274).

National governments introduced labor reforms and set themselves the task to control social problems at the national level. These measures were motivated in part by the willingness to decrease the potential abuse of power and control of paternalist employers and came together with a partial withdrawal of business from the social and political sphere-a political de-responsabilization of business.

\section{American Corporate Capitalism and Managerial Trusteeship}

Another pattern of business-society interactions where business played a significant role was managerial trusteeship. Trusteeship emerged and co-evolved together with 
corporate and managerial capitalism, during the first half of the twentieth century in the United States.

\section{Historical Context: The Emergence of Corporate and Managerial Capitalism}

At the turn of the twentieth century, the American capitalist landscape went through a "great transformation" associated with corporatization and rapid "managerialization" (Berle and Means 1932; Chandler 1977; Roy 1997; Sklar 1980). This "great transformation" had no equivalent anywhere else in the world and the form of capitalist organization that emerged then was peculiar to the United States. This emergent form of capitalism had a number of defining features (Djelic and Amdam 2007).

The large-size and capital-intensive firm was one of its key markers (Chandler 1977, 1990) and it was associated with an oligopolistic understanding of competition policed by antitrust regulation (McCraw 1997). The constitution of large firms co-evolved with a change in legal status: the joint stock corporation with dispersed ownership imposed itself (Roy 1997; Sklar 1980). Those corporations were listed on stock exchanges where they found the capital they required (Navin and Sears 1953). Professional managers-without ownership legitimacy - increasingly imposed themselves as key decision makers (Berle and Means 1932). This separation between ownership and control was a major revolution. It triggered the emergence of a profession-managementand the structuring of an organizational field around it (McKenna 2006; Sutton et al. 1956).

The consequence of this revolution was a profound reinvention of the dominant form of capitalism in the United States (Djelic and Amdam 2007; Sklar 1980). Well until the second half of the nineteenth century, American capitalism had been of the proprietary-competitive type and hence quite similar to European forms of capitalism. Most industries were structured around small or medium-sized firms. Personal and family ownership combined with a discourse championing free competition that was, however, mitigated by the reality of cartel-like strategies that attempted to curb competition and its problematic consequences (Djelic 1998). In just a few decades, American capitalism came to be re-invented around very large-size firms, oligopolistic competition, corporate ownership, and the managerialization of decision making. The transformation was striking indeed and highly consequential (Berle and Means 1932; Sklar 1980).

\section{Trusteeship and Its Ideological Frame: Techno- Managerial Efficiency}

While this form of capitalism was being institutionalized, discussions were intense as to its consequences.
Contradictory notions had to be reconciled- "bigness" on the one hand with an axiomatic belief in competition on the other but also the disappearance of owners (replaced by invisible, dispersed, and un-involved shareholders) with a sense of corporate responsibility.

The process took time and was conflictual but a social compromise finally emerged. This social compromise was the background ideology that framed trusteeship as an emerging pattern of business-society interactions. We label it "techno-managerial efficiency." "Efficiency" was the central notion in that social compromise, allowing for the reconciliation of "bigness" with "free competition." Efficiency was perceived to create a positive dynamic for the consumer that largely compensated for the reduction in competition. Since ownership had essentially dissolved into the holding of pieces of paper, managers inherited power. This power, particularly because of the large size of firms, had to be coupled with significant responsibility. And this responsibility extended well beyond the boundaries of the firm. It was conceived as a "quasi-public responsibility" and, as a consequence, corporations (through their managers) should become major political actors both on the national and even further on the international scene. This political role was understood in managerial-technocratic terms, the idea being to tackle broad political issues also through managerial "efficiency" and professionalization.

As the size and number of corporations increased rapidly in the first decades of the twentieth century, their social significance became clearer (Heald 1970, p. 61). In an article written in 1932 and titled "For Whom are Corporate Managers Trustees," Edwin Merrick Dodd, a Harvard Law School Professor put it clearly:

Modern large-scale industry has given to the managers of our principal corporations enormous power over the welfare of wage earners and consumers, particularly the former. Power over the lives of others tends to create on the part of those most worthy to exercise it a sense of responsibility (Dodd 1932, p. 1157).

As management developed, in parallel, into a quasiprofession, this new position of powerful mediator had to be defined along with associated responsibilities. The Harvard Business Review (HBR), first published in 1922, and the American Management Association (AMA), established in 1923, played a key role in that respect. A 1923 article of the AMA journal, the Management Review, stated the following: "We are beginning to regard those who occupy executive positions as having something in the nature of quasi-public responsibility" (Heald 1970, p. 64). The 1929 crisis only reinforced the urgency of discussions on and around the responsibility of corporations and their 
leaders, the new "managers." The concentration of power-economic, financial, but also political-in the hands of a small number of firms became all the more striking and problematic as conditions were worsening for many across the country.

This period of American capitalism has sometimes been referred to as the 'trusteeship management' era (Hay and Gray 1974) and we take over that label. Elbert H. Gary, President and Chairman of the Board of the US Steel Company argued in 1921 that managers occupied a "position of balance" and were in fact "trustees for investors, employees, employers, consumers, or customers, competitors, and all others who may be interested in or affected by, the actions or attitudes of the managers" (cited in Heald 1970, p. 100). The manager had a "fiduciary duty" in other words towards many different groups and in fact towards society broadly understood. In striking contrast to what Friedman would claim in 1970, professional managers seemed perfectly legitimate in that period to make decisions not only on behalf of their companies but also on behalf of multiple stakeholder groups.

\section{Political Roles and Responsibilities}

In that context, corporations-through their managerswere hence called upon to take on political roles and responsibilities of different kinds but all of significance. As they inscribed themselves in the peculiar ideological frame we have just described, those roles and responsibilities became justified and legitimate.

\section{Social Rights: Serving the Public Interest through Community Chests}

As the management profession was being institutionalized, the idea that corporations - through their managers-had the duty to serve the public interest came to be clearly articulated. The Harvard Business School that became in the 1920s a leading "producer" of professional managers played a key role in that respect (Khurana 2010). Wallace B. Donham, Dean of the School, was adamant that the key challenge of the times was to create the conditions for the emergence of a socially responsible managerial class that would know how to mobilize corporate capitalism to serve the public interest broadly understood:

Unless more of our business leaders learn to exercise their powers and responsibilities with a definitely increased sense of responsibility toward other groups in the community, unless without great lapse of time there is through the initiative of such men an important socializing of business, our civilization may well head for one of its periods of decline (Donham 1927).
Similarly, Leverett Lyon, an official of the Chicago Association of Industry and Commerce, suggested that business education had "to make crystal clear...that business does not exist for itself but is a device which society uses and modifies for the accomplishment of social purposes" (Lyon 1922, cited in Heald 1970, p. 79).

Calls for a particular kind of corporate 'citizenship' were made as early as in the 1920s and in fact well before the Great Depression (Eberstadt 1973, p. 22). Owen D. Young, who was then Chairman of General Electric and representative of a generation of public minded businessmen and managers put it this way:

Customers have a right to demand that a concern so large shall not only do its business honestly and properly, but, further, that it shall meet its public obligations and perform its public duties-in a word, vast as it is, that it should be a good citizen (Young 1929).

A concrete form in which this corporate responsibility manifested itself was through the community chest movement (Heald 1970). As the individual philanthropy of the great American Robber Barons (Carnegie or Rockefeller) gave way to corporate philanthropy, corporate managers increasingly became involved in the development of community fund drives designed to support social needs - e.g., health or education (Zunz 2011). For example, "massive fundraising campaigns were organized between 1921 and 1925 to endow universities" (Hoffman 2007, p. 67). In addition, corporations also offered their workers pension plans, consumer credit, unemployment insurance, or profit sharing schemes and they "engaged in public works and philanthropic projects such as community health and welfare, the arts and education" (Hoffman 2007, p. 66). By the end of the 1920s, (corporate) business, through its professional managers, had become in the United States a "key social institution" for the well-being of the community (Heald 1970, p. 198).

\section{Defending a Form of Civilization and Its Associated Civil Rights}

The unprecedented power and size of American corporations made salient, already in the 1910s and 1920s, their political nature and role (Dodd 1932; Donham 1927). This political role was sometimes connected to the increasing power of the United States on the world scene-and to the responsibility this entailed in the face of ever increasing risks and threats (Spector 2008; Yogev 2001). From a geopolitical perspective, the political and social involvement of American corporations hence could have a stabilizing aim. It could help save "American liberalism" from 
the threats and challenges it was facing and this would be done through

...socialization of industry from within on a higher ethical plane, not socialism or communism, not government operation or the exercise of political power, but rather the development from within of effective social control (Donham 1927, p. 407).

In his 1927 HBR article, "The Social Significance of Business," Donham acknowledged the urgency of facing up to this upcoming "threat to civilization":

The discontent with the existing condition of things is perhaps more widespread than ever before in history. There is a close analogy between the position of the governing class in the earlier, simple societies [France and Russia at the time of their revolutions] and that of the business group in our present complex social organization (Donham 1927, p. 406).

Donham went on, making it clear that it was the responsibility of corporate managers to protect "the continuance of our economic order and its sane evolution" (Donham 1927, p. 407). Starting with the First World War, an important political responsibility of American business was seen to be, nationally and internationally, the championing of an American way of life-as defined through mass-production and mass-consumption in a (corporate) market society. American business had, in other words, the responsibility to defend a particular kind of civilization in the face of mounting threats. Henry Ford proposed his own interpretation of this responsibility, first strongly contested then widely supported and defended. He asserted that progress (economic, social, and moral) was fueled by massconsumption and that the responsibility of business was thus to offer quality products at low prices. From that perspective, "the logic of mass production thus reconciled the private interest of the manufacturer with the well-being of the consumer, and, ultimately, with society at large" (Heald 1970, p. 89).

\section{Political Rights: Ministering to the Needs and Desires of a Broad Constituency}

The projection of management as having the capacity and the duty to serve the public interest and hence to be a "trustee" for the interests of multiple parties was significantly challenged by the onset of the 1929 crisis. The early years following the crisis were years of bitter disappointment as it became plain that corporate managers had not adequately served and protected the public interest-quite to the contrary. The Great Depression revived anti-big business sentiment in the United States-within civil society but also among politicians (Roosevelt 1936). On the side of corporations and their leaders, one of the reactions to re-establish public legitimacy was to take on a greater share of responsibility in a situation of immense social distress.

With a view to improve public relations, Ford's "gospel of production" turned into the "gospel of service." Henry Gantt, an early management consultant, defined "service" as a way to ensure "more democratic principles in business" (Hoffman 2007, p. 62). This new gospel of service was quite demanding on managers:

The gospel of service was clearly more ambitious than the gospel of production. It demanded of its apostles both a sense of trusteeship and a desire to put one's will and work at the service of others (Fortune editors 1949, p. 156).

The gospel of service was picked up by emerging public relations firms and advertising agencies who saw the broad public as their constituency. They committed to determining the wants of this constituency and ensuring that manufacturers would satisfy them:

Just as citizens had representatives in Congress looking out for their needs and interests, so consumers had a representative in the highest councils of business, demanding that their desires be satisfied (Marchand 1985, p. 30).

Greater involvement in the Community Chest movement was another path to demonstrating "service" (Elwood 1932; Heald 1970; Zunz 2011). To palliate resentment, but also to keep government at bay, large corporations rushed into "responsible" corporate philanthropy. In 1932, Louis E. Kirstein, President of the Associated Jewish Philanthropies of Boston, candidly expressed the rationale:

Either we must give generously and voluntarily to our social agencies or we must stop whining when government is forced to impose the added taxes required for succor until jobs appear (Kirstein 1932).

Corporate spending increased from $\$ 2,539,819$ by 2652 firms in 13 cities in 1920 to $\$ 12,954,769$ by 33,977 firms in 129 cities in 1929 (Heald 1970, p. 18). By then, business contributions had become a key element in the chests' funding movement not only in the form of monetary donations but also in the form of strong personal involvement leading to the creation of broad networks that connected local chests into a nationally organized charity.

However, philanthropy did not prove sufficient to deal with mass unemployment after 1929. Starting in the early 1930s, the New Deal marked an assertive attempt, on the part of governmental authorities, to impose themselves on the territory of social welfare. A bitter struggle opposed the government to business and community chests in the 1930s 
on the question of tax deductions for corporate donations. The stake was the continued capacity of business to maintain its vast community spending and community organizing. The New Deal government was not in favor of tax deduction schemes as it sought to constrain corporate influence in social and political matters and to expand instead the role and responsibilities of government. Eventually, after years of lobbying from business and community chests, the Five Per Cent Amendment was voted in 1935. This allowed companies to deduct payments to charitable organizations for up to $5 \%$ of their taxable income. This legitimated the use of corporate funds for social purposes but also appeased critics of corporate giving within and around firms-corporate philanthropy became "good for business" as it reduced the overall tax bill (Hoffman 2007, p. 67).

\section{Questioning Trusteeship and the Assertion of Government}

During the 1910s and 1920s, trade associations played an important role-along with the new business schools-as a "professionalizing force" (Heald 1970, p. 92). They were at the forefront in pushing the notion of (corporate) managers as legitimate professional trustees for the public interest. They set industry standards and were active in establishing ethical codes of conduct. They also justified business self-regulation as the most (cost-)effective pattern of regulation-hence serving the common and public interest. Already in the 1920 s, though, a number of critics were questioning this. The economist J.M. Clark, for example, called in 1926 for "social accounting"_-arguing that the current situation where the private sector was in charge of its own control could not protect the interests of the public at large.

After 1929, the federal government became increasingly assertive-with the large corporations being one of its main targets. As FD Roosevelt is believed to have said then in private corridors "we have to save capitalism from itself" (Schlesinger 1958). A number of business leaders tried to fight back - attempting to protect private business and its self-defined political roles and responsibilities from encroachments by the New Deal government, particularly as the latter was deploying an ambitious regulatory program (Katznelson 2014). Shortly before the 1936 elections, Colby M. Chester of General Mills called business to do all it could to "win public approbation" (Heald 1970, p. 194).

Other business leaders chose a different path. By the end of the 1930s, some of the most emblematic managers of large American corporations came to re-invent what was meant by the political involvement of managers. The New Deal and its ambitious project of national flexible planning created opportunities for those managers to take their sense of political duty to a new level. An exemplary illustration of that evolution is the Committee for Economic Development (CED) (Collins 1981). The CED was created in 1942 by a group of progressive businessmen together with the American Secretary of Commerce, Jesse Jones. Paul Hoffman, Chairman of the Studebaker Corporation, William Benton from the advertising firm of Benton and Bowles, and Marion Folsom, treasurer of the Eastman Kodak Company, were all, among others, founding members. The agenda of the CED was to involve the American business community in national planning for the postwar period and to determine the conditions necessary to preserve employment. The group of progressive businessmen who made up the CED had come to terms with the New Deal. They accepted a degree of government intervention in the economy and recognized that the state should lead the way when it came to social welfare and the administration of social, civil, and political rights (Collins 1981).

The 1929 crisis and its partial de-legitimation of corporate managers' claims to trusteeship opened the way to an increasingly assertive federal government. This evolution contributed to the delineation of a sharp boundary between what came to be defined as the responsibility of business (serving the interests of the firm and later on of shareholders in particular) and what pertained of a politi$\mathrm{cal} /$ social sphere. Even if corporations and their managers could be called upon to take on parts of those political and social responsibilities, the idea that they should be doing this as surrogates of the state emerged during that period and came to progressively impose itself.

\section{Discussion: Contextualizing Contemporary Political CSR}

Our ideal-typical exploration of two distinct historical patterns of business-society interactions shows that firms had played significant social and political roles well before the contemporary period of neoliberal globalization. We propose the idea of contextual and functionally equivalent patterns that inscribe themselves in distinct ideological frames.

\section{Learning from Two Historical Ideal-Types of Business-Society Interactions}

In nineteenth century Europe, paternalist employers created and sustained public goods and institutions, provided material and welfare benefits of various kinds, attending to the needs of workers and their families from "cradle to grave." They imposed moral and ideological "guidance," shaping the context in which workers and their families could enjoy civil rights. They also set rules for entire 
communities within and around their factories, closely controlling and monitoring employees not only at work but also well into their private lives. By the turn of the twentieth century, an organized labor movement influenced in part by the socialist critique and increasingly assertive national governments came to scrutinize and question the legitimacy of the strong political engagement of private business. Key arguments were that paternalism led to the structural infantilization of workers and that it gave employers too much (illegitimate) power and discretion.

In the first decades of the twentieth century, as American capitalism went through its great transformation, the social and political responsibility of corporations was source of intense discussions. The size and power of those corporations implied, it was argued, great social significance-and, as a consequence, carried responsibilities. Since ownership had essentially dissolved into the holding of pieces of paper, the emerging group of professional managers took over this power and associated responsibilities. Those professional managers were supposed to be "trustees" of the public interest, with a responsibility to balance the interests of multiple groups. They were also expected to contribute to the defense, both nationally and internationally, of a particular form of civilization. Through the active coordination of a nation-wide philanthropy movement, they furthermore indirectly framed the context for collective and civic action on a large scale. The 1929 crisis and the ensuing de-legitimation of corporate managers' claims to trusteeship opened the way for an increasingly assertive federal government. FD Roosevelt's New Deal project had in part the objective to affirm the pre-eminence of the state on social and political territories. It could be seen, from that perspective, as an attempt to assert government's responsibility for the common good and to contain the pretensions of business on that front.

The empirical exploration showed that business assumed, in both periods, strong social and political responsibilities. The "null hypothesis" that business and government, economics and politics were (by nature)—or should be-clearly separated could be argued to emerge, in fact, at the end of each period, during the rise to prominence of the welfare state in Europe and during the confrontation, in the 1930s, between the New Deal government and American business. The historical contextualization of contemporary CSR and its political role presented above allows us to put into perspective the takenfor-granted separation of private and public spheres that serves as a benchmark for current theorizing on the political role of CSR. We propose an alternative "null hypothesis"- business and state responsibilities are tightly interconnected, often blurred and always being negotiated. Firms play today as they did in the past important political roles. Hence, globalization is not per se the driver of the political role of business (Whelan 2012). Nevertheless, as the embodiment of neoliberal ideology, contemporary globalization shifts the ways in which business engages in various political but also social roles.

\section{Neoliberal Globalization and Its Significant Moderating Role}

"Globalization" is an oft-debated concept that has been associated with diverse definitions. We connect it here to two main trends. First, the globalization we are talking about is "neoliberal" (Campbell and Pedersen 2001). The onset of this contemporary wave of globalization parallels the global spread of the neoliberal agenda that became, in the same period, integrated with corporate capitalism (Djelic 2006; Mirowski and Plehwe 2009). Neoliberal globalization has been characterized by a powerful trend towards the maximization of shareholder value, as we argued above, and towards marketization. The term "marketization" refers both to market ideologies and market-oriented reforms. Contemporary market ideology reflects the belief that markets are of superior efficiency for the allocation of goods and resources. Market-oriented reforms are those policies fostering the emergence and development of markets and weakening, in parallel, alternative institutional arrangements (Djelic 2006; Simmons and Elkins 2004). A second defining feature of contemporary globalization is the associated density of regulatory and governance activities with a transnational scope and reach (Djelic and Sahlin-Andersson 2006; Levi-Faur and Jordana 2005). Many different actors are involved in these activities—states but also multinational corporations, international organizations, and non-governmental organizations. An important role for those multi-stakeholder platforms is to codify, frame, and standardize practices, in particular by negotiating and issuing rules, norms, or standards.

Contemporary CSR has clear American roots (e.g., Sheehy 2014). But CSR as we know it today has also become embedded and inscribed through time in the progress of corporate capitalism and its transformation under neoliberal globalization (Scherer et al. 2009; Segerlund 2010). The global trend towards explicit CSR identified by Matten and Moon (2008) illustrates this co-evolution. Along with the diffusion of explicit CSR as a set of practices has come the spread of a neoliberal understanding that CSR was something unnaturally tied to business and could be at most a voluntary engagement (Höllerer 2013). As Richter points out:

The CSR debate relies on a strict separation of the public and private domain derived from the liberal model. The liberal assumption of a minimalist state 
guaranteeing the free exercise of private interests and avoiding government coercion is translated into the voluntary character of CSR in the CSR debate (Richter 2010, p. 634).

Hence, contemporary globalization has neoliberal underpinnings and contemporary CSR practices remain anchored within this paradigm. This neoliberal inscription has a number of consequences for the ways in which businesssociety interactions play out on the ground within contemporary CSR. This becomes all the more obvious when we systematically compare and contrast neoliberal CSR with our two historical ideal-types.

\section{Differences and Similarities: Comparing Contemporary CSR with Paternalism and Trusteeship}

The systematic comparison between contemporary CSR and our two historical ideal-types allows us to identify four principal dimensions along which the political role of firms has varied over time and in parallel to shifting ideological frames-territory, main actors, targets, and modes of responsibility.

\section{Territory: From Local to Global}

The evolution, all the way from paternalism to contemporary corporate social responsibility, has come with a broadening of the range of action and of target territorieshence with a certain form of geographic universalization. When we compare contemporary CSR to paternalism or trusteeship, we realize that the temporal move also corresponds to an extension of territory, as it were, of the common good. Paternalism localized political responsibility; the firm was in charge of a narrow geographical community. In the 1920-1930s, the trusteeship era expanded the horizon of the political role of firms/corporations to the national territory. Contemporary CSR has the world as its territory, at least potentially.

Political CSR scholars note that within this global territory, multinational corporations (MNCs) fill institutional and governmental voids particularly in developing countries. That business takes on political responsibilities vis-àvis weak national governments is not in itself a new development, as nineteenth century paternalism shows. What differs, though, is the nature of the firms (MNCs) that take on a political role in local communities and their global reach and power.

More specific perhaps to our contemporary era is the strong involvement of firms as political and rule-making actors in the international/transnational context. When talking of corporate political activities, one needs to differentiate between the levels at which they occur. At the local or national level, there might be no significant difference in nature or even in intensity with the political roles exerted (well) before globalization. At the global level, however, an entirely new space has been created for the political activity and involvement of business.

\section{New Actors: Towards a Virtualization of Actorhood}

Under paternalism, the actors that became strongly engaged in political and social activities were essentially family or personal firms with strong anchoring in a regional (and hence national) territory. During the trusteeship era, the main actors were the new mostly nationally based joint stock corporations of a re-invented American capitalism. After 1929, those national corporations joined forces through philanthropy networks-and those networks then became important relays of the social and political engagement of individual corporations.

As a consequence of its global diffusion, CSR has today become structured as a broad and fluid transnational field, with a multiplicity of nodes in relations of co-opetition with each other (Levy and Kaplan 2008). The constellation of actors is characterized by the fact that transnational actors such as MNCs and multinational non-governmental organizations (NGOs) play a major role compared to most local actors or even to nation states. It is no surprise then, that national governments across the world establish their own transnational champions by controlling MNCs and creating GONGOs, "governmental non-governmental organizations" as a means to regain influence at the global level (Cumming 2010).

\section{Targets and Intentions: From Concrete to Elusive}

Under paternalism, the targets of the social responsibility and political activity of firms were real and intentions were concrete-workers, their families and their welfare, and a well-delineated local community and its prosperity. During the trusteeship era, the targets were a dematerialized but still identifiable national "citizen" and a physical national territory. Intentions were structured around the defense of a particular form of civilization (with a national base). In the context of contemporary CSR, targets are the "global citizen" or the "global environment" and intentions are articulated around the elusive notion of the "global common good" - a notion that is highly dematerialized and quite difficult to grasp.

The new political turn of CSR acknowledges the great power of MNCs at the global level-mirroring the local power of the paternal firm and the national power of the American corporation. What Clark called in 1926 the role of "social accounting" (Clark 1926) - the potential of civil 
society to influence and control public matters-has translated today into the role of a dense ecology of mediators (consultants, NGOs, the media, ranking and accreditation bodies,...) that hold business accountable on a global scale. In the process, the ultimate targets are being displaced to quite an extent-from the subjects and objects towards which the corporation engages its responsibility (even in their elusive and disembodied form) towards, at least in part, this dense ecology of mediators and watchdogs.

\section{New Modes: The De-Materialization of Responsibility}

The expansion of territories and the "virtualization" of targets have come together with the progressive de-materialization of responsibility. Early paternalist owners could clearly be identified as "real" individuals or families-and they directly bore the responsibility for the social and political engagement of their firms. The early American corporation acting in the public interest was already a somewhat more dematerialized actor. However, in the context of weak and dispersed ownership, professional managers came to embody corporate responsibility. Today, pointing to the locus of responsibility(ies) in the context of CSR is highly challenging if not outright impossible. Corporations are understood to "belong to their shareholders" (Friedman 1970) and hence the responsibility should lie there. What does it mean though to have an assembly of dispersed and fluid shareholders as ultimate responsibility bearers for CSR? If anything, it makes it difficult to apply a "liability model of responsibility" where "one assigns responsibility to particular agents whose actions can be shown as causally connected to the circumstances for which responsibility is sought" (Young 2004, p. 368).

Furthermore, the more we move away from paternalism and closer to contemporary CSR, the more we see the strong role of discourse over actions in the management of social and political responsibility. Naturally, the paternalist owner or manager did build discursive strategies around his actions (Coffey 2003) but those actions took center stage and they could be concretely, physically identified and experienced (e.g., the utopian familistère of Godin or housing developments for workers around paternalist factories). A key issue with contemporary CSR is that of the decoupling between increasingly dense discursive products and actions that are becoming difficult to follow, experience, and monitor. This generates many outcries of "green" or "ethical" washing (Tokar 1997). The tools mobilized to monitor social engagement and corporate social responsibility are those of the "audit society" (Power 1997). Audits and measurements are used to produce multiple systems of "naming and shaming" (Boli 2006) - (positive and negative) rankings, accreditations, and evaluations. This move towards a "measurability" of responsibility is hailed as an important step leading to transparency and efficiency. But the measurability and "quantification" of responsibility are also creating the opportunity and the possibility for its commodificationwhat is more, on a global scale. Arguably, this process of commodification of responsibility could emerge as the driver of collective irresponsibility (Mitchell 2002).

In Table 1, we bring together and summarize those three different forms:

As we have shown above, the common good was in private hands before it came to be, historically, "nationalized." The rise of the welfare state in Europe and the deployment of the American New Deal were reactions, in part, to the strong discretionary power of private business that had ruled until then. The project was to move towards an at least partial nationalization of social responsibilities with a view to marginalizing the power of private firms. We agree with Matten et al. (2003, p. 116) and Beck (1995, p. 98) that the "equation of politics and the state" is "a modernist category error." We hope to have provided evidence that the privatization of the common good is not a consequence of globalization. We can, however, come to re-interpret the contemporary CSR movement as a case of partial re-privatization of the common good, a partial "return to the past" but under different conditions.

The re-privatization of the common good that comes together with contemporary CSR means that private economic actors enjoy (again) a fair degree of discretionary power. This principle of discretionary power is stable across the background ideologies presented above. The ideological frames of authoritarian benevolence, managerial efficiency, and shareholder wealth maximization all take for granted that private actors voluntarily have the legitimacy to engage in political roles and responsibilities. Those private actors, and in particular the large corporations, have a relative free hand in the targeting of certain constituencies over others, in the selection of certain issues and priorities over others, of certain tools over others, as long as they remain within a general framework that is so broad as to really constrain nothing (e.g., the Global Compact). This is reminiscent, indeed, of the greater degree of discretionary power traditionally associated with paternalism and managerial trusteeship, a discretionary power against which the (welfare) state and the American New Deal had both attempted to fight.

\section{Implications for Future Research: Overcoming the Democracy Gap}

Hence, we can and should learn from the historical shortcomings of paternalism and trusteeship and reflect upon contemporary (political) CSR and its own limitations. 
Table 1 Political responsibility in historical perspective

\begin{tabular}{llll}
\hline & Paternalism & Trusteeship & CSR \\
\hline $\begin{array}{l}\text { Ideological } \\
\text { frame }\end{array}$ & $\begin{array}{l}\text { Authoritarian-owner } \\
\text { benevolence } \\
\text { Territory }\end{array}$ & Techno-managerial efficiency & Shareholder value maximization \\
Actors & Family or personal firms & National & National corporations and philanthropy networks \\
Targets & $\begin{array}{l}\text { Workers, families, } \\
\text { communities }\end{array}$ & $\begin{array}{c}\text { Tocal communities, national citizens, and national } \\
\text { (MNCs, NGOs...) }\end{array}$ & $\begin{array}{c}\text { The global citizen, the global environment, } \\
\text { global common good }\end{array}$ \\
Modes & Employers (direct) & Managers (per delegation) & $\begin{array}{c}\text { Corporations and multi-actor platforms (diffuse } \\
\text { and partly indirect) }\end{array}$ \\
\hline
\end{tabular}

The discretionary, and as a consequence limited and partial, nature of paternalism, and trusteeship generated negative reactions. Those features indeed came, through time, to be identified as problematic. Neither paternalism nor trusteeship could be seen as fully legitimate in their claims of serving "the common good," nor even of handling "the social question." The ultimately private nature of firms and the conflicts this generated, their limited and highly discretionary reach and scope meant that political engagement on their part could always be shown to be wanting and to lack legitimacy. The development of the welfare state in Europe and the deployment of the New Deal in the United States were attempts, in part, to overcome the limits of a system that strongly relied on private actors by granting national governments a significant role. Governments had, by nature, a "universal" national reach, scope, and responsibility and were, at least formally, legitimate over a given national territory.

These historical debates and criticisms appear to lend empirical support to current critical readings of political CSR and they specifically raise questions about the limits and legitimacy of corporate discretionary political choices (Banerjee 2007; Buchholz and Rosenthal 2004). In part as a reaction to those issues, democratization mechanisms aiming at stakeholder participation and empowerment are increasingly identified as necessary conditions for the legitimacy of corporate political involvement (Dallmayr 2003; Matten and Crane 2005b; Palazzo and Scherer 2008; Renouard and Lado 2012). Scherer and Palazzo turn to Habermas and propose deliberative democracy as a legitimizing process for corporate political involvement (Palazzo and Scherer 2006; Scherer and Palazzo 2007). Others develop the notion of "stakeholder democracy" (Crane et al. 2005; Harrison and Freeman 2004; Matten and Crane 2005b; Thompson and Driver 2005). Stakeholder democracy can be understood as "firm-stakeholder relations based on self-governing and voluntarism" (Matten and Crane 2005b, p. 10) and implies that stakeholders obtain a right to participate in decision-making processes, to sit at the table (Crane et al. 2005, p. 72).

At one extreme, some scholars have argued against stakeholder democracy as it undermines the legitimacy of corporate and managerial authority (Van Oosterhout 2007). At the other extreme, the claim is that this does not go far enough given the fundamental question of who is to be included or excluded for the debate to be really democratic (Parker 2002). The argument is that deliberative democratic processes may in fact be de-politicizing rather than re-politicizing. Even if there is agreement on who should sit at the table, significant power differences de facto imply the silencing of marginalized or dissonant voices (Edward and Willmott 2012). This is reminiscent of the evolution from controlling worker morality to defending civil rights by paternalist firms. Because only certain kinds of employee representation were allowed, this development was still taming the political debate rather than opening it.

Our critique of CSR is more radical, we propose, than the one set out by political CSR scholars. Indeed, the political CSR literature tends to champion corporate and managerial voluntarism in the context of transnational deliberative and participatory platforms as a possible path towards a defense of the "common good." But owner or managerial discretion was precisely the main factor that prevented, historically, both paternalism and trusteeship from "serving the common good." Hence, based on our historical analysis, we argue that corporate and managerial discretion and voluntarism at the transnational level are not likely to be the solutions to social, environmental, and political ills nor are they likely to be the best path to "serving the common (global) good." On the basis of this analysis, and in line with certain critics, we therefore call for a more radical approach to stakeholder democracy in global governance (Edward and Willmott 2008, 2012; Whelan 2012). Whelan, for example, proposes that political CSR needs to 
be associated with a 'political' model of corporate governance that provides communities, citizenries, and/or civil society, with similar voting rights to those that shareholders enjoy within shareholder corporate governance models (Whelan 2012, p. 719).

Based on our historical contextualization of CSR and its redefinition as one form of business-society interactions reflecting a unique ideological frame, we encourage future research on the "democracy gap and (how to) make corporate decisions more accountable" (Scherer and Palazzo 2011, p. 921). As we argue here, in line with Mäkinen and Kourula (2012), the political responsibilities of business can take different forms-and those forms reflect in part underlying ideologies. Contemporary CSR is and remains deeply inscribed within a neoliberal frame. And a multi-stakeholder re-interpretation of global political CSR does little as yet to challenge this deep inscription. If we are to overcome some of the problematic shortcomings of contemporary (political) CSR, we will need to disembed it from its associated neoliberal ideological frameand attempt to connect it with an alternative worldview.

One way in which to start doing this is to think about the implications today, at the transnational level, of the solutions devised historically to deal with the shortcomings of private political engagement. The European welfare state and the American New Deal both made two common claims-formal legitimacy and universalism. The question for us today is what could be the contemporary functional equivalent, at the transnational level, of these kinds of solutions.

\section{Conclusion}

By exploring and comparing paternalism in nineteenth century Europe, managerial trusteeship in early twentieth century US, and contemporary CSR, we underscored important differences as well as striking similarities. All periods are characterized by business taking on strong political roles and responsibilities, with high managerial discretion. These roles and responsibilities nevertheless differed in expanding the territory from local to global reach. Actors evolved from family firms to transnational multi-actor constellations, and went from targeting local communities to global stakeholders. Finally, responsibility was progressively dematerialized-from the original concrete and direct responsibility of the paternal employer to diffuse and more indirect forms of corporate responsibility. This historical contextualization shows that the frontier between economy and polity has always been blurry and shifting. Hence, we propose that Friedman's "null hypothesis" of a clear separation between business and state responsibilities, far from describing a natural state of things, reflects in reality a singular and limiting perspective-deeply anchored in neoliberal ideology. Furthermore, we suggest that this powerful ideological frame and its associated "null hypothesis" have been the source of and have fueled the taken-for-grantedness of the principle of voluntarism in the (political) CSR literature.

In light of our reading of the two historical ideal-types, we may question whether a voluntary and deliberative democratic platform is sufficient to address the externalities and welfare issues associated with globalized business and to legitimize the strong political involvement of business. While we are sympathetic to the idea of a possible democratization of corporate processes (Scherer and Palazzo 2007), we agree with Mäkinen and colleagues $(2012,2014)$ or Whelan (2012) that Habermas' political theory may not be sufficient to bring along the democratization needed in the context of contemporary challenges. If we started from an alternative, historically informed, null hypothesis, that business and state responsibilities are tightly interconnected, often blurred, difficult to disentangle, and always being negotiated, we could develop a more radical view of stakeholder democracy for the proper governance of business activities-one that goes well beyond the power and discretion of private corporate actors. This, we hope, opens new perspectives and research avenues with a view to refine our understanding of contemporary CSR and its political dimension.

Acknowledgments The authors would like to thank two anonymous reviewers and the Editors of the Special Issue for very useful comments and suggestions throughout the revision process.

\section{References}

Acquier, A., Gond, J. P., \& Pasquero, J. (2011). Rediscovering Howard R. Bowen's legacy: The unachieved agenda and continuing relevance of social responsibilities of the businessman. Business \& Society, 50, 607-646.

Baden-Fuller, C., \& Morgan, M. (2010). Business models as models. Long Range Planning, 43(2-3), 156-171.

Banerjee, S. B. (2007). Corporate social responsibility. Cheltenham: Edward Elgar.

Banerjee, S. B. (2011). Voices of the governed: Towards a theory of the translocal. Organization, 18(3), 323-344.

Beck, H. (1995). Origins of the authoritarian welfare state in Prussia, 1815-1870. Ann Arbor, MI: University of Michigan Press.

Bentham, J. (1995). The panopticon writings. Ed. and intro. M. Bozovic. London: Verso.

Berle, A., \& Means, G. (1932). Modern corporation and private property. London and New York: Macmillan.

Boli, J. (2006). The rationalization of virtue and virtuosity in world society. In M. L. Djelic \& K. Sahlin-Andersson (Eds.), Transnational governance (pp. 95-118). Cambridge: Cambridge University Press. 
Buchholz, R., \& Rosenthal, S. (2004). Stakeholder theory and public policy: How governments matter. Journal of Business Ethics, 51(1), 143-153.

Campbell, J., \& Pedersen, O. (Eds.). (2001). The rise of neoliberalism and institutional analysis. Princeton, NJ: Princeton University Press.

Carroll, A. (2008). A history of corporate social responsibility: Concepts and practices. In A. Crane, D. Matten, A. McWilliams, J. Moon, \& D. Siegel (Eds.), The Oxford handbook of corporate social responsibility (pp. 19-46). Oxford: Oxford University Press.

Chandler, A. (1977). The visible hand. Cambridge, MA: The Belknap Press.

Chandler, A. (1990). Scale and scope. Cambridge, MA: Harvard University Press.

Cheal, D. J. (1979). Hegemony, ideology and contradictory consciousness. The Sociological Quarterly, 20(1), 109-117.

Clark, J. M. (1926). Social control of business. Chicago: University of Chicago Press.

Coffey, J. (2003). Léon Harmel. Notre Dame, IN: University of Notre Dame Press.

Colli, A., Perez, P., \& Rose, M. (2003). National determinants of family firm development. Enterprise and Society, 4(1), 28-64.

Collins, R. (1981). The business response to Keynes, 1929-1964. New York: Columbia University Press.

Crane, A., Driver, C., Kaler, J., Parker, M., \& Parkinson, J. (2005). Stakeholder democracy: Towards a multi-disciplinary view. Business Ethics: A European Review, 14(1), 67-75.

Crane, A., \& Matten, D. (2008). Fear and loathing in the JCC: Unleashing the monster of 'New Corporate Citizenship Theory' to confront category crisis. Journal of Corporate Citizenship, 29(March), 21-24.

Crane, A., Matten, M., \& Moon, J. (2004). Stakeholders as citizens? Rethinking rights, participation, and democracy. Journal of Business Ethics, 53(1-2), 107-122.

Cumming, L. (2010). GONGOs. In H. K. Anheier \& S. Toepler (Eds.), International encyclopedia of civil society (pp. 779-783). New York: Springer.

Dallmayr, F. (2003). Cosmopolitanism moral and political. Political Theory, 31(3), 421-442.

Davies, W., \& McGoey, L. (2012). Rationalities of ignorance: On financial crises and the ambivalence of neo-liberal epistemology. Economy and Society, 41(1), 64-83.

Debouzy, M. (1988). Permanence du paternalisme? Le Mouvement Social, 3-16.

De Bry, F. (1980). Le paternalisme dans l'opinion des industriels français au XIXème siècle. Unpublished doctoral dissertation, Université de Paris-I.

De Geer, H., Borglund, T., \& Frostenson, M. (2009). Reconciling CSR with the role of the corporation in Welfare States: The problematic Swedish example. Journal of Business Ethics, 89(3), 269-283.

Devinney, T. M. (2009). Is the socially responsible corporation a myth? The good, the bad, and the ugly of corporate social responsibility. Academy of Management Perspectives, 23(2), $44-56$.

Djelic, M. L. (1998). Exporting the American model. Oxford: Oxford University Press.

Djelic, M. L. (2006). Marketization: From intellectual agenda to global policy making. In M. L. Djelic \& K. Sahlin-Andersson (Eds.), Transnational governance (pp. 53-73). Cambridge: Cambridge University Press.

Djelic, M. L., \& Amdam, R. P. (2007). Americanization in comparative perspective: The managerial revolution in France and Norway, 1940-1990. Business History, 49(4), 483-505.
Dodd, E. (1932). For whom are corporate managers trustees? (pp. 1145-1163). XLV: Harvard Law Review.

Donham, W. B. (1927). The social significance of business. Harvard Business Review, II, 401-419.

Doty, H., \& Glick, W. (1994). Typologies as a unique form of theory building: Toward improved understanding and modeling. Academy of Management Review, 19(2), 230-251.

Eberstadt, N. (1973). What history tells us about corporate responsibilities. Business and Society Review, 7, 76-81.

Editors, Fortune. (1949). The moral history of U.S. business. Fortune, $X L(6), 143-158$

Edward, P., \& Willmott, H. (2008). Corporate citizenship: Rise or demise of a myth? Academy of Management Review, 33(3), 771-773.

Edward, P., \& Willmott, H. (2012). Discourse and normative business ethics. In C. Lütge (Ed.), Handbook of the philosophical foundations of business ethics (pp. 549-580). Dordrecht: Springer.

Elwood, S. (1932). Discussion of some sociological principles underlying the community chest movement. Social Forces, 10(4), 494

Engels, F. (1987 [1844]). The condition of the working class in England. London: Penguin Books.

Esping-Andersen, G. (1990). The three worlds of welfare capitalism. Princeton University Press.

Fleming, P., \& Jones, M. (2012). The end of corporate social responsibility. Thousand Oaks, CA: Sage Publications.

Fooks, G., Gilmore, A., Collin, J., Holden, C., \& Lee, K. (2013). The limits of corporate social responsibility. Journal of Business Ethics, 112(2), 283-299.

Friedman, M. (1970). The social responsibility of business is to increase its profits. New York Times Magazine, September 13. Last retrieved January 2014 from http://www.colorado.edu/ studentgroups/libertarians/issues/friedman-soc-resp-business. html.

Garriga, E., \& Melé, D. (2004). Corporate social responsibility theories: Mapping the territory. Journal of Business Ethics, 53(1/ 2), 51-71.

Gillet, M. (1976). La grève d'Anzin de 1884 et Germinal. Cahiers Naturalistes, XXII(50), 59-66.

Glaser, B. (2002). Conceptualization: On theory and theorizing using grounded theory. International Journal of Qualitative Methods, 1(2), 23-38.

Godin, J. B. (1881). Comment s'accomplit le progrès social ? Le Devoir, February 27, 129-130.

Gueslin, A., \& Jones, M. (1993). Michelin, les hommes du pneu. Paris: Ed. ouvrières.

Guiol, P. (2000). L'expérience Godin ou les 'équivalents de la richesse'. Panoramiques, 46(2), 94-104.

Hacking, I. (1990). Two kinds of 'New Historicism' for philosophers. New Literary History, 21(3), 343-364.

Hall, J. (2007). Historicity and sociohistorical research. In W. Outhwaite \& S. Turner (Eds.), The Sage handbook of social science methodology (pp. 82-99). Thousand Oaks, CA: Sage.

Harmel, L. (1889). Catéchisme du patron. Paris: Aux bureaux du journal la corporation.

Harrison, J. S., \& Freeman, R. E. (2004). Special topic: Democracy in and around organizations. Academy of Management Executive, 18(3), 49-53.

Harvey, D. (2005). A brief history of neoliberalism. Oxford: Oxford University Press.

Hay, R., \& Gray, E. (1974). Social responsibilities of business managers. Academy of Management Journal, 17(1), 135-143.

Heald, M. 2005 [1970]. The social responsibilities of business. New Brunswick: Transaction Publishers. 
Heath, J., Moriarty, J., \& Norman, W. (2010). Business ethics and (or as) political philosophy. Business Ethics Quarterly, 20(3), 427-452.

Hernes, T. (2005). Four ideal-type organizational responses to New Public Management reforms and some consequences. International Review of Administrative Sciences, 71(1), 5-17.

Hirschman, A. (1981). Essays in trespassing. Cambridge: Cambridge University Press.

Hobsbawm, E. (1996[1962]). The age of revolution: 1789-1848. Vintage: First Vintage Books Edition.

Hoffman, R. (2007). Corporate social responsibility in the 1920s: An institutional perspective. Journal of Management History, 13(1), 55-73.

Höllerer, M. A. (2013). From taken-for-granted to explicit commitment: The rise of CSR in a corporatist country. Journal of Management Studies, 50(4), 573-606.

Horsfall, D. (2013). A fuzzy set ideal-type approach to measuring the competition state. Policy and Society, 32(4), 345-356.

Hounshell, D. (1984). From the American system to mass production: 1800-1932. Baltimore, MD: Johns Hopkins University Press.

Ite, U. (2004). Multinationals and CSR in developing countries: A case study of Nigeria. Corporate Social Responsibility and Environmental Management, 11(1), 1-11.

Jones, M. T., \& Haigh, M. (2007). The transnational corporation and new corporate citizenship Theory. Journal of Corporate Citizenship, 27, 51-69.

Joyce, P. (1980). Work, society and politics: The culture of the factory in later Victorian England. Oxford: Taylor \& Francis.

Kalb, D. (1997). Expanding class: Power and everyday politics in industrial communities, The Netherlands 1850-1950. Durham, NC: Duke University Press.

Kaplan, R. (2015). Who has been regulating whom, business or society? The mid-20th-century institutionalization of "corporate responsibility" in the USA. Socio-Economic Review, 13(1), $125-155$.

Katznelson, I. (2014). Fear itself: The New Deal and the origins of our time. New York: Liveright.

Katznelson, I., \& Zolberg, A. R. (Eds.). (1996). Working-class formation. Nineteenth century patterns in Western Europe and the United States. Princeton, NJ: Princeton University Press.

Khurana, R. (2010). From higher aims to hired hands. Princeton, NJ: Princeton University Press.

Kieser, A. (1989). Organizational, institutional and societal evolution: Medieval craft guilds and the genesis of formal organization. Administrative Science Quarterly, 34(4), 540-564.

Kinderman, D. (2012). 'Free us up so we can be responsible!' The coevolution of CSR and neo-liberalism in the UK, 1977-2010. Socio-Economic Review, 10(1), 29-57.

Kirstein, L. E. (1932). The challenge to businessmen. The Survey, October 15, 501-503.

Lallement, M. (2009). Le travail de l'utopie. Paris: Les Belles Lettres.

Levi-Faur, D., \& Jordana, J. (Eds.) (2005). The rise of regulatory capitalism. In The annals of the American academy of political and social science, Vol. 598. London: Sage.

Levy, D., \& Kaplan, R. (2008). CSR and theories of global governance: Strategic contestation in global issue arenas. In Crane, A., McWilliams, A., Matten, D., Moon, J., \& Siegel, D. (Eds.), The Oxford Handbook of CSR. Oxford: Oxford University Press.

Lyon, L. (1922). Education for business. Chicago: University of Chicago Press.

Mackey, A., Mackey, T., \& Barney, J. (2007). Corporate social responsibility and firm performance: Investor preferences and corporate strategies. The Academy of Management Review, $32(3), 817-835$.

Magnusson, L. (2000). An economic history of Sweden. London: Routledge.
Mäkinen, J., \& Kasanen, E. (2014). Boundaries between business and politics: A study on the division of moral labor. Journal of Business Ethics. doi:10.1007/s10551-014-2419-x.

Mäkinen, J., \& Kourula, A. (2012). Pluralism in political corporate social responsibility. Business Ethics Quarterly, 22(4), 649-678.

Mäkinen, J., \& Kourula, A. (2013). Globalization, national politics and corporate social responsibility. In R. Tainio, S. Merilainen, J. Mäkinen, \& M. Laihonen (Eds.), Limits of globalization (pp. 219-235). Copenhagen: Copenhagen Business School Press.

Marchand, R. (1985). Advertising the American dream. Berkeley: University of California Press.

Marens, R. (2008). Recovering the past: Reviving the legacy of the early scholars of corporate social responsibility. Journal of Management History, 14(1), 55-72.

Marens, R. (2012). Generous in victory? American managerial autonomy, labour relations and the invention of corporate social responsibility. Socio-Economic Review, 10(1), 59-84.

Marens, R. (2013). What comes around: The early 20th century American roots of legitimating corporate social responsibility. Organization, 20(3), 454-476.

Margolis, J. D., \& Walsh, J. P. (2003). Misery loves companies: Rethinking social initiatives by business. Administrative Science Quarterly, 48, 268-305.

Mark-Ungericht, B., \& Weiskopf, R. (2007). Filling the empty shell. Journal of Business Ethics, 70(3), 285-297.

Matten, D., \& Crane, A. (2005a). Corporate citizenship: Toward an extended theoretical conceptualization. Academy of Management Review, 30(1), 166-179.

Matten, D., \& Crane, A. (2005b). What is stakeholder democracy? Perspectives and issues. Business Ethics, 14(1), 6-13.

Matten, D., Crane, A., \& Chapple, W. (2003). Behind the mask: Revealing the true face of corporate citizenship. Journal of Business Ethics, 45(1-2), 109-120.

Matten, D., \& Moon, J. (2008). Implicit" and "explicit" CSR. Academy of Management Review, 33(2), 404-424.

Mauss, M. (1967[1925]). The Gift. Norton, MA: Norton Library.

McCraw, T. (Ed.). (1997). Creating modern capitalism. Cambridge, MA: Harvard University Press.

McKenna, C. D. (2006). The world's newest profession: Management consulting in the twentieth century. Cambridge University Press.

McWilliams, A., \& Siegel, D. (2001). Corporate social responsibility: A theory of the firm perspective. Academy of Management Review, 26(1), 117-127.

Mena, S., \& Palazzo, G. (2012). Input and output legitimacy of multistakeholder initiatives. Business Ethics Quarterly, 22(3), 527-556.

Mirowski, P., \& Plehwe, D. (Eds.). (2009). The road from Mont Pèlerin. Boston: Harvard University Press.

Mitchell, L. (2002). Corporate irresponsibility. New Haven, NJ: Yale University Press.

Navin, T., \& Sears, M. (1953). The Rise of a market for industrial securities, 1887-1902. Business History Review, 29(2), 105-123.

Nielsen, N. J. (1994). Lifelong care and control paternalism in nineteenth-century factory communities. Ethnologia Scandinavica, 24, 70-89.

Noiriel, G. (1988). Du "patronage" au "paternalisme". Le Mouvement Social, 144, 17-35.

Nussbaum, F. (2002[1933]). An early history of the economic institutions of Europe. Washington, DC: Beard Books.

Padelford, W., \& White, D. W. (2009). The shaping of a society's economic ethos: A longitudinal study of individuals' morality of profit-making worldview. Journal of Business Ethics, 85(1), $67-75$.

Palazzo, G., \& Scherer, A. G. (2006). Corporate legitimacy as deliberation: A communicative framework. Journal of Business Ethics, 66(1), 71-88. 
Palazzo, G., \& Scherer, A. (2008). Corporate social responsibility, democracy, and the politicization of the corporation. Academy of Management Review, 33(3), 773-775.

Parker, C. (2002). The open corporation. Cambridge: Cambridge University Press.

Polanyi, K. (1944). The great transformation. Boston: Beacon Press.

Pollard, S. (1965). The genesis of modern management. London: Penguin.

Power, M. (1997). The audit society. Oxford: Oxford University Press.

Prakash, A., \& Griffin, J. (2012). Corporate responsibility, multinational corporations, and nation states: An introduction. Business and Politics, 14(3), 1-10.

Quadagno, J. (1987). Theories of the welfare state. Annual Review of Sociology, 1, 109-128.

Quinn, M. (1997). The fallacy of non-interference: The poor panopticon and equality of opportunity. Journal of Bentham Studies, 1, 1-18.

Reid, D. (1985). Industrial paternalism. Comparative Studies in Society and History, 27(4), 579-607.

Renouard, C., \& Lado, H. (2012). RSE et justice sociale: Le cas des multinationales pétrolières dans le Delta du Niger. Afrique et Développement, 37(2), 167-194.

Richter, U. (2010). Liberal thought in reasoning on CSR. Journal of Business Ethics, 97(4), 625-649.

Roberts, D. (1958). Tory paternalism and social reform in early Victorian England. The American Historical Review, 63(2), 323-337.

Roosevelt, F.D. (1936). A rendezvous with destiny. Speech before the 1936 National Democratic Convention, Philadelphia, June 27. Retrieved 20 October 2014 from http://www.austincc.edu/ lpatrick/his2341/fdr36acceptancespeech.htm.

Rotter, J. P., Airike, P.-E., \& Mark-Herbert, C. (2014). Exploring political corporate social responsibility in global supply chains. Journal of Business Ethics, 125(4), 581-599.

Roy, W. (1997). Socializing capital. Princeton, NJ: Princeton University Press.

Sabel, C., \& Zeitlin, J. (1985). Historical alternatives to mass production: Politics, markets, and technology in nineteenthcentury industrialization. Past and Present, 108, 133-176.

Scherer, A. G., \& Palazzo, G. (2007). Toward a political conception of corporate social responsibility. Academy of Management Review, 32(4), 1096-1120.

Scherer, A. G., \& Palazzo, G. (2011). The new political role of business in a globalized world. Journal of Management Studies, 48(4), 899-931.

Scherer, A. G., Palazzo, G., \& Matten, D. (2009). Introduction to the special issue: Globalization as a challenge for business responsibilities. Business Ethics Quarterly, 19(3), 327-347.

Schlesinger, A. (1958). The coming of the New Deal-The age of Roosevelt (Vol. 2). Boston: Hougthon Mifflin.

Schmid, H. (1981). On the origin of ideology. Acta Sociologica, 24(1-2), 57-73.

Screpanti, E., \& Zamagni, S. (2005). An outline of the history of economic thought (2nd ed.). Oxford: Oxford University Press.

Segerlund, L. (2010). Making CSR a global concern. Farnham: Ashgate Publishing.

Sheehy, B. (2014). Defining CSR: Problems and solutions. Journal of Business Ethics. doi:10.1007/s10551-014-2281-x.

Simmons, B., \& Elkins, Z. (2004). The globalization of liberalization. American Political Science Review, 98(1), 171-189.
Sklar, M. (1980). Corporate reconstruction of American capitalism, 1890-1916. New York: Cambridge University Press.

Skocpol, T. (Ed.). (1984). Vision and method in historical sociology. New York: Cambridge University Press.

Soliva, R. (2007). Landscape Stories: Using ideal type narratives as a heuristic device in rural studies. Journal of Rural Studies, 23(1), 62-74.

Somers, M. (1995a). What's political or cultural about political culture and the public sphere? Towards an historical sociology of concept formation. Sociological Theory, 13(2), 113-144.

Somers, M. (1995b). Narrating and naturalizing civil society and citizenship theory: The place of political culture and the public sphere. Sociological Theory, 13(3), 229-274.

Spector, B. (2008). Business responsibilities in a divided world. Enterprise \& Society, 9(2), 314-336.

Sutton, F., Harris, S., Kaysen, C., \& Tobin, J. (1956). The American business creed. Cambridge, MA: Harvard University Press.

Thompson, G., \& Driver, C. (2005). Stakeholder champions: How to internationalize the corporate social responsibility agenda. Business Ethics, 14(1), 56-66.

Tokar, B. (1997). Earth for sale. Boston: South End Press.

Tone, A. (1997). The business of benevolence: Industrial paternalism in corporate America. Ithaca: Cornell University Press.

Van Dijk, T. A. (1998). Ideology: A Multidisciplinary Approach. London: Sage.

Van Dülmen, R. (1989). Industriekultur an der Saar: Leben und Arbeit in einer Industrieregion 1840-1914. Munich: Beck.

Van Oosterhout, H. (2005). Corporate citizenship: An idea whose time has not yet come. The Academy of Management Review, $30(4), 677-681$.

Van Oosterhout, H. (2007). Authority and democracy in corporate governance? Journal of Business Ethics, 71(4), 359-370.

Vogel, D. J. (2005). Is there a market for virtue? The business case for corporate social responsibility. California Management Review, 47(4).

Watkins, J. (1952). Ideal types and historical explanation. The British Journal for the Philosophy of Science, 3(9), 22-43.

Weber, M. (1949[1904]). 'Objectivity' in social science and social policy. In Shils, E. \& Finch, H. (Eds.), Max Weber: The methodology of the social sciences. Glencoe: The Free Press.

Weber, M. (1978[1922]). Economy and society. Berkeley: University of California.

Whelan, G. (2012). The political perspective of corporate social responsibility: A critical research agenda. Business Ethics Quarterly, 22(4), 709-737.

Willke, H., \& Willke, G. (2008). Corporate moral legitimacy and the legitimacy of morals: A critique of Palazzo/Scherer's communicative framework. Journal of Business Ethics, 81(1), 27-38.

Yin, R. (2014). Case-study research: Design and methods. Thousand Oaks, CA: Sage.

Yogev, E. (2001). Corporate hand in academic glove-The case of the Harvard group in the 1920's. American Studies International, 39(1), 52-71.

Young, O. (1929). Address of Owen D. Young, January 1929. In J. Sears (Ed.), The new place of the stockholder (p. 209). New York: Harper \& Brothers.

Young, I. M. (2004). Responsibility and global labor justice. The Journal of Political Philosophy, 12(4), 365-388.

Zunz, O. (2011). Philanthropy in America: A history. Princeton, NJ: Princeton University Press. 